\title{
Impact of personal cultural orientations and cultural intelligence on subjective success in self-employment in multi-ethnic societies
}

\author{
Martin Mabunda Baluku, ${ }^{1,3^{*}}$, Julius Fred Kikooma ${ }^{1}$, Edward Bantu ${ }^{2}$, Peter Onderi ${ }^{4}$ and Kathleen Otto ${ }^{3}$
}

\author{
* Correspondence: mbaluku1@ \\ gmail.com; mbaluku@chuss.mak.ac. \\ ug \\ 'Department of Educational, \\ Organizational and Social \\ Psychology, Makerere University, \\ School of Psychology, P.O Box 7062, \\ Kampala, Uganda \\ ${ }^{3}$ Faculty of Psychology, Work and \\ Organizational Psychology, \\ Philipps-Universität, Gutenbergstr \\ 18, D-35032 Marburg, Germany \\ Full list of author information is \\ available at the end of the article
}

\begin{abstract}
The purpose of this paper is to assess the impact of personal cultural orientation and behavioral aspect of cultural intelligence on subjective success in self-employment in a multi-ethnic context. Based on Sharma (J Acad Mark Sci 38: 787-806, 2010) taxonomy of personal cultural orientations, the paper examines the impact of interdependence and social inequality orientations on subjective success in selfemployment (measured in terms of job satisfaction). Self-employed individuals working in multiethnic communities in East Africa (Uganda and Kenya) were compared with their counterparts in Germany operating in a less culturally or ethnically diverse context. Moderated mediation analysis using PROCESS macro model 8 is applied to measure the direct and indirect effects. Interdependence and social inequality cultural orientations were positively related to subjective success in self-employment for the East African sample, but not for the Germany sample. The results revealed that the impact of these cultural orientations on subjective success is mediated by behavioral cultural intelligence. However, these indirect effects vary between Germany and East Africa. Similar to cross-cultural settings, multiethnic business settings involve doing business with people from various ethnic and linguistic backgrounds. This requires the entrepreneur to behave in a manner that demonstrates appreciation and respect of other people's cultures.

Keywords: Behavioral cultural intelligence, Entrepreneurial success, Interdependence, Personal cultural orientations, Self-employment, And social competencies
\end{abstract}

\section{Introduction}

Self-employment has emerged as an alternative career path for young people rather than searching for opportunities in traditional paid employment. Economic and labor market dynamics have played a big role. The unemployment challenge has persisted since the times of the most recent global financial crisis (Dietrich \& Möller, 2016; Reinhart \& Rogoff, 2009; Vogel, 2015b). In such circumstances, career mobility, including going into entrepreneurship is important path to transitioning and succeeding in the labor market (Baluku, Löser, Otto, \& Schummer, 2018). Thus self-employment has increasingly become a practical career alternative particularly for young people in countries with high youth unemployment rates (Baluku, Bantu, \& Otto, 2018; Falco \& Haywood, 2016; Vogel, 2015a).

(c) The Author(s). 2019 Open Access This article is distributed under the terms of the Creative Commons Attribution 4.0 International License (http://creativecommons.org/licenses/by/4.0/), which permits unrestricted use, distribution, and reproduction in any medium, provided you give appropriate credit to the original author(s) and the source, provide a link to the Creative Commons license, and indicate if changes were made. 
In addition to young people's challenge of transiting from school to work, governments are under pressure to reduce unemployment as well as provide sustainable decent employment as advocated for by Sustainable Development Goal 8 (Frey et al., 2016; Gore, 2015; Parisotto, 2015). Coupled with the need for improving economic development indexes, self-employment, and or entrepreneurship are being promoted as the most feasible solution. Consequently, self-employment is on the rise (Falco \& Haywood, 2016) and playing an important role in the economics of developing countries. Particularly, it is the leading form of employment (70\% of employed persons) in low-income countries (Gindling \& Newhouse, 2014). Self-employment rates will continue to rise given the changing nature of labor market and work dynamics including movement towards service sector, globalized labor market and, increase in the population of skilled and semi-skilled immigrants (Fritsch, Kritikos, \& Rusakova, 2012).

The benefits of self-employment to individuals and the economy, however, can only be realized if the self-employment projects are successful. Particularly, individuals may not persist in self-employment if their goals are not met or if they are dissatisfied in this form of employment. Gindling and Newhouse (2014) revealed that only $7 \%$ of the self-employed in developing countries are successful. Previous research has predominantly measured success in objective terms considering aspects such as income, profitability, and growth (Baluku, Kikooma, \& Kibanja, 2016b; Baron, Franklin, \& Hmieleski, 2016). In the present study, we focus on subjective success, measured in terms of job satisfaction. We presume that the value of success dimensions such as income and improved welfare is best reflected in the extent to which business owners are satisfied in their roles as self-employed.

The study of predictors of business performance is also dominated by a focus on human capital and financial factors (e.g. Caliendo et al., 2015; Coleman, 2007; Cooper et al., 1994; Neeley and Van Auken, 2009). However, Gindling and Newhouse (2014) survey of self-employed in 74 countries revealed that approximately a third of unsuccessful entrepreneurs share similar characteristics; confirming the proposition that success is also impacted on by the personal characteristics of the entrepreneur (Baluku, 2017; Baluku et al., 2016b; Gideon \& Baron, 2003). In the present study, we particularly focus on personal level cultural variables. Whereas culture is widely studied in the entrepreneurial literature, extant research has explained national cultures that are conducive to entrepreneurship development and success (e.g. Hayton and Cacciotti 2013; Nabi and Liñán 2013) based on Hofstede's model (Hofstede, 1984; Hofstede \& Minkov, 2010; Hofstede, 1994).

The argument in this paper is that personal cultural orientations and cultural intelligence are also factors that contribute to success in self-employment, depending on the cultural context. Entrepreneurship literature shows that people who start enterprises tend to have similar values and beliefs across countries (McGrath, MacMillan, Yang, \& Tsai, 1992), suggesting that personal values rather than national culture matter most. Sharma (2010) presents ten (10) personal cultural orientations that operationalize Hofstede's five (5) dimensions of national culture (Hofstede, Hofstede, \& Minkov, 2010; Minkov \& Hofstede, 2011) at the individual level. The study specifically focuses on two (2) of the ten (10) personal cultural orientations; namely interdependence and social inequality. These dimensions relate to collectivism and power distance or hierarchy or egalitarian as represented in Hofstede $(1984,2011)$ and Schwartz (1994) models. These 
personal cultural orientations specifically concern how individuals relate with others, hence are contributors to how entrepreneurs relate to other people in the business environment. Whereas cultures that emphasize interdependence are deemed less conducive for entrepreneurship, they have been found to play certain roles in entrepreneurial development (Tiessen, 1997; Zeffane, 2014; Zhao, Li, \& Rauch, 2012).

These cultural orientations are particularly relevant to entrepreneurship because of their relationship to social skills and behavior. Previous research has already demonstrated that social competencies such as the ability to have quality interactions are essential for entrepreneurial success (Baluku, Kikooma, Bantu, \& Otto, 2018; Baron \& Markman, 2000, 2003; Markman \& Baron, 2003). In this direction, the present study examines whether cultural intelligence (a socio-cultural competence) mediates the relationship between personal cultural orientations and success in self-employment in a multiethnic context. Cultural intelligence is an important factor for behavior in multicultural settings (Ott \& Michailova, 2016). However, even within a given culture, there are wider intra-cultural variations ( $\mathrm{Au}, 2000$; Fischer, 2006), hence cultural intelligence is also important in such contexts. In a multiethnic context, entrepreneurs are required to adjust their cultural behaviors so that they can do business with individuals from other ethnicities. Hence, the present study particularly focuses the behavioral cultural intelligence dimension, which concerns the ability to adapt behavior to the cultural setting (Chao, Takeuchi, \& Farh, 2017; Van Dyne et al., 2012).

Therefore, the purpose of this study is to extend entrepreneurship culture research by examining the impact of personal cultural orientations and behavioral cultural intelligence on subjective success in self-employment; based on assumptions that social competencies are critical for entrepreneurial success (Baron and Markman 2003). First, the paper examines the relationships of personal cultural orientations (interdependence and social inequality) with subjective success (job satisfaction). Second, the paper shows that cultural intelligence mediates the impact of these cultural orientations on subjective success in self-employment. Third, the paper shows that these relationships vary among countries based on the level of multiculturalism or multi-ethnicity.

\section{Theory and hypotheses development}

Markman and Baron (2003) propose that social competence plays an important role in entrepreneurial success. Social competence, in the entrepreneurial field, concerns an entrepreneur's ability to effectively interact with others including employees, customers, suppliers, and other stakeholders in the business. Social competence includes the ability to read others, making good first impressions, adapting to a range of social situations and persuasiveness (Baron and Markman 2000). The present study extends these assumptions (theory) by suggesting that in a multiethnic setting, entrepreneurs require to add cultural skills (cultural intelligence) to these social skills to enable them to have effective interactions with people from other cultural or ethnic backgrounds. The paper proposes that this is also dependent on a person's cultural orientations.

\section{Personal cultural orientations and self-employment}

Cultural research in the field of entrepreneurship has chiefly concentrated on differentiating entrepreneurial from non-entrepreneurial cultures (e.g. Hayton \& Cacciotti, 2013; 
Li \& Zahra, 2012; Mueller \& Thomas, 2001). The effect of the values on behavior extends to entrepreneurial situations and activities (McGrath et al., 1992). Whereas culture is largely studied at national or society level following Hofstede's model, it has been highlighted that personal level cultural values cannot be ignored. Within a given culture, individuals significantly vary in their predominant orientations (Au, 2000; Fischer, 2006). We presume that individual-level cultural values are more proximal than the national cultural values, to a person's behavior. Hence our focus on the individual level cultural orientations rather than the national cultural dimensions. Moreover, personal cultural orientations have not been widely studied in entrepreneurship research. We therefore still develop our hypotheses based on literature related to the Hofstede model.

To enable measurement of Hofstede's cultural dimensions at the personal, Sharma (2010) reconstructed these dimensions into a taxonomy of 10 Personal Cultural Orientations (PCOs). As a good framework for understanding how different societies deal with social issues (Minkov and Hofstede, 2011), the Hofstede model has provided the basis for entrepreneurial culture research in recent decades. This research has shown that dominant cultural norms and practices have an influence on entrepreneurial activities in a given society (Autio, Pathak, and Wennberg 2013; Li and Zahra 2012; Wennberg, Pathak, and Autio 2013; Tlaiss 2014; Davidsson 1995; Huggins and Thompson 2014).

At the individual level, cultural values are essential for entrepreneurs in developing, accumulating and using cultural and human resource practices that enhance entrepreneurial performance (Chand \& Ghorbani, 2011). Consequently, one's cultural values can, directly and indirectly, affect success via interpersonal competencies. In the following subsections, we show how Sharma derives social inequality and interdependence personal cultural orientations from the Hofstede model, and hypothesize about the likely relationship of social inequality orientations and interdependence with subjective success in self-employment.

\section{Social inequality cultural orientation}

Sharma (2010) derives the personal cultural orientation of social inequality from the "power dimension" of the Hofstede model. In small-power distance societies, there are minimal inequalities and interdependence; while large-power distance societies are characterized by high levels of inequality and are polarized between dependence and counter-dependence (Minkov \& Hofstede, 2012; Mintu, 1992). However, based on the logic that presenting power distance dimension on a horizontal and vertical axis does not adequately show the difference in power and equality. Sharma (2010) conceptualizes this dimension into two personal cultural orientations: power and social inequality. Sharma defines these orientations in line with (Schwartz, 1992, 1994) values of hierarchy and egalitarianism. Hence, power refers to the degree of acceptance of power differences among members of a community; while social inequality concerns the degree of acceptance of inequality among members.

Previous research regarding the impact of power and inequality issues on entrepreneurship have predominantly used Hofstede model, and shows that entrepreneurial behavior is favored in low-power distance cultures (Eroglu \& Picak, 2011; Tlaiss, 2014; Vinogradov \& Kolvereid, 2010; Wennekers, Thurik, Van Stel, \& Noorderhaven, 2010). 
In high Power Distance societies, power is concentrated within a small group of individuals, while the majority has limited power. This has an effect on innovative and risk-taking behavior (Fernandez, Carlson, Stepina, \& Nicholson, 1997; Sun, 2009), thus impacting negatively on entrepreneurial behavior. However, it could also be claimed that social inequality orientation is positively related to entrepreneurship and entrepreneurial success; whereby entrepreneurship is used as a platform for reducing social inequalities in society. For example, work-family conflicts tend to push women into business (Thébaud, 2010). In the context of social inequality, entrepreneurship is seen as a means of empowerment to the marginalized (Al-Dajani \& Marlow, 2013). This is also in line with the thinking that entrepreneurship is a feasible solution to some of the challenges related to social inequality, for example, in alleviating poverty (Bruton et al. 2013) and reducing unemployment (Vogel, 2015a). Moreover, in line with social competence assumptions of Baron and Markman (2003), entrepreneurs who recognize and value social differences among members of society are likely to have better approaches to relate with different customers and stakeholders, which improves customer impressions and network ties. Hence it is hypothesized that:

H1. Social inequality orientation correlates positively with subjective success in self-employment.

\section{Interdependence cultural orientation}

The interdependence orientation is derived from the individualistic-collectivistic dimension of the Hofstede model (Sharma, 2010); which concerns the relationship between the person and the society; or precisely the degree of cohesiveness or looseness of ties among individuals in a group (Franke, Hofstede, \& Bond, 1991). Whereas these appear to be two ends of a continuum, there is literature suggesting that a person may have both individualistic and collectivistic tendencies (Oyserman, 2006). Based on these shortfalls and the alternatives provided in the self-construal model (Markus \& Kitayama, 1991) and the personal cultural values (Schwartz 1992), Sharma re-conceptualizes this dimension into independence and interdependence orientations, which are purportedly negatively related. Independence involves preference to act independently, freedom, personal achievement, autonomy and strong self-concept (Sharma, 2010). Contrary, interdependence involves preference to act in groups, reliance on others, attention to the group over personal goals and collective achievement.

Research on entrepreneurship culture suggests that business is more suited to cultures where individual rather than collective action is emphasized (Dubina \& Ramos, 2016; Huggins \& Thompson, 2014). However, regarding success, Rauch et al. (2013) noted that collectivistic tendencies are also important for the implementation of innovations. Particularly, it has been linked to women entrepreneurship (Bullough, Renko, \& AbdelZaher, 2013); is essential for entrepreneurial development in so-called collectivistic countries (e.g. Zeffane 2014), and also relevant for social entrepreneurship (Pathak \& Muralidharan, 2016). In relation to the social competence assumptions, interdependence is also related to the ability to establish external ties (Tiessen, 1997). These abilities are useful for obtaining external financing and marketing, which are linked to success indicators. It is therefore hypothesized that: 
$H 2$. Interdependence orientation correlates positively with subjective success in self-employment.

\section{Cultural intelligence and self-employment}

In today's highly globalized economy, few businesses are operating in a confined uni-cultural context. Cultural diversity in all societies is increasingly inevitable, hence entrepreneurs are increasingly engaged in cross-cultural business. Their ability to adjust to doing business with individuals from a differing culture, or doing business in a cultural context different from their own is therefore important. Such capability fits with what has been labeled cultural intelligence (Earley and Peterson 2004; Crowne 2008; Earley and Mosakowski 2004; Earley 2002). This form of intelligence has been defined as the ability to interact effectively with people from different cultures (Soon \& Linn, 2015; Tuleja, 2014); and this involves the ability to shape and exhibit appropriate behavior in a different or new cultural setting (Thomas 2006).

Such capability is needed for the self-employed to be able not only do business in cross-cultural settings, but also recognizing and respecting differences as well as reconciling and adjusting in such situations (Earley \& Mosakowski, 2004; Magnusson, Westjohn, Semenov, Randrianasolo, \& Zdravkovic, 2013; Rauch et al., 2013; Soon \& Linn, 2015). Moreover, such capability is still important in domestic businesses (Peus, Frey, Gerkhardt, Fischer, \& Traut-Mattausch, 2009) given reduced cultural homogeneity of communities. In the same community, individuals differ on a variety of aspects that require cultural understanding and adjustment such as language, sexual orientation, ethnicity, religion, social class, and political affiliation (Triandis, 2006). Thus the justification for the studies of cultural intelligence and belief that cultural intelligence is an interactional asset for different professionals (Erez et al., 2013; McNulty, Mackay, Lewis, Lane, \& White, 2016; Thomas, Lazarova, \& Inkson, 2005; Watkins \& Noble, 2016). Several components of cultural intelligence have been proposed (cf: Van Dyne et al. 2012; Lange 2012). In the present study, we concern ourselves with the behavioral aspects of cultural intelligence, given that this is more proximal to the behavior of entrepreneurs in the business space.

Cultural intelligence may be vital for the self-employed at the different stages of the entrepreneurial activity; from the formation of self-employment intentions to opportunity recognition, entry, and success. Existing research shows that cultural intelligence is related to entrepreneurial intentions and performance (Jiang \& Park, 2012; Magnusson et al., 2013) including the abilities to recognize and willingness to exploit cross-national or cross-cultural business opportunities. This is reflected in the link between cultural intelligence and commitment to study international business (Ramsey, Barakat, \& Aad, 2014) and the export performance of small business owners (Charoensukmongkol, 2016). Cultural intelligence is also an important competency for decision making, effective teamwork, leadership, management and negotiations (Brislin, Worthley, \& Macnab, 2006; de la Garza Carranza \& Egri, 2010; Earley \& Mosakowski, 2004; Earley, 2002) as well as motivating creativity (Bogilović \& Škerlavaj, 2016). All these are essential in the process of managing one's own business. Competition in the contemporary business world is no longer localized. Therefore, a culturally diversified team is required, bringing together different cultural resources for a team. Evidence suggests that cultural diversity within the 
business and in the operating environment does help gain and maintain competitive advantage (Groves \& Feyerherm, 2011). However, the business owner needs the capability to harness and manage such a resource.

The daily life of a self-employed or entrepreneur is by nature stressful (Baron et al., 2016). Taking risks of investing, competition, dealing with conflicts and loss are some of the issues that confront the self-employed person. It gets worse when operating in cultures that are unfamiliar, or making business dealings with individuals whose beliefs and practices are different. The challenge arises especially if we cannot understand the intentions and behaviors of stakeholders, which are linked to culture. With regards to this, cultural intelligence has been found related to emotional intelligence (Crowne 2013; Earley and Mosakowski 2004; Lin, Chen, and Song 2012), which is further an important tool for resilience and adjustment (Houghton, Wu, Godwin, Neck, \& Manz, 2012) and entrepreneurial success (Sarwar, Nadeem, \& Aftab, 2017). This increases the likelihood of succeeding in self-employment role. It is therefore hypothesized that:

H3. Behavioral cultural intelligence is positively related to subjective success in self-employment.

We further posit that interdependence and social inequality cultural orientations sensitize people to the peculiarities of each social contact. Hence they enhance one's cultural intelligence, and consequently able to conduct business in a multi-ethnic context. Whereas some scholars question the existence of a cognitive capability called cultural intelligence, there is agreement that culture has influences on the development of such individual abilities. Sternberg (2004) provides a framework in which intelligence is culturally determined; specifically, that culture does not only influence the development of intelligence but also the way intelligence is conceptualized and its significance. There are a few studies that have attempted to measure the effect of culture on different intelligence constructs. These few studies, however, demonstrate that culture indeed has an influence on different forms of intelligence such as emotional (Gunkel, Schlaegel, \& Engle, 2014) and cultural intelligence (Chao et al., 2017). We, therefore, would like to test an exploratory assumption that cultural orientations are related to cultural intelligence. Given that culture impacts both entrepreneurial success and cultural intelligence, we would like to hypothesize that the effect of cultural orientations on success in self-employment is partly mediated by cultural intelligence. Cultural intelligence is a competence that increases the capability of the entrepreneur to deal with clients of different cultural and ethnic backgrounds. In line with the assumption that social competencies are related to entrepreneurial success (Baron \& Markman, 2003), we particularly propose that cultural intelligence is important for interactional tasks of the entrepreneur, which translates into performance and consequently improving subjective success. Based on the above arguments, we hypothesize that:

$H 4 a$. Both interdependence and social inequality cultural orientations are positively related to cultural intelligence.

$H 4 b$. Cultural intelligence mediates the effect of both interdependence and social inequality cultural orientations on subjective success in self-employment. 
The context is essential to understanding entrepreneurship; including an understanding of antecedents and outcomes (Nabi, Liñán, Fayolle, Krueger, \& Walmsley, 2017; Smallbone \& Welter, 2006; Welter, 2011). We, therefore, posit that the effect of personal cultural orientation and cultural intelligence are dependent on the wider cultural environment and the country's development. This is also supported by Frederking (2004) observation that the role of culture in business varies among societies. That is, in some but not all societies, cultural values, and norms are extended to economic activities. Nonetheless, even in societies where cultural values are separated from the business process, the general cultural effect on character extends to entrepreneurial behavior. This includes the perception of barriers, support mechanisms, and personal competencies to engage in entrepreneurial activities (Migliore, 2011; Shinnar, Giacomin, \& Janssen, 2012); development and usage of social capital (Chand \& Ghorbani, 2011). In addition, values are closely linked to social and political circumstances (McGrath et al., 1992); which have implications for self-employment (Gindling and Newhouse 2014). It is therefore expected that the direct effects of personal cultural values on subjective success in self-employment vary among countries given the differences in social, political and economic conditions; which factors may also affect the degree to which cultural values are applied to economic behavior. Keeping note that cultural intelligence is a competence that particularly enables individuals to interact with people from other cultural backgrounds (Earley \& Mosakowski, 2004; Earley, 2002; Soon \& Linn, 2015), it is also expected that the indirect effects of personal cultural orientation on subjective success via behavioral cultural intelligence also differ among countries, depending on the level of multiculturalism or multi-ethnicity of the business context. Most communities in East Africa are multiethnic and multi-linguistic. For example, Uganda has over 40 native ethnic groups (Naluwooza, 2017). Moreover, business hubs tend to have a greater collection of most ethnicities and languages. On the other hand, the comparison country, Germany is more homogeneous in terms of culture and language. In addition, East Africa is predominantly a collectivistic society, where interdependence is highly valued (Baluku, Bantu, \& Otto, 2018). On the contrary, Germany has a high individualistic orientation (Guess, 2004). These are likely to affect the utility of interdependence and cultural intelligence in entrepreneurial activities. It is therefore hypothesized that:

$H 5 a$. The direct effects of interdependence and social inequality cultural orientations on subjective success in self-employment are higher for East Africa than for Germany. $H 5 b$. The indirect effects of interdependence and social inequality cultural orientations on subjective success in self-employment via cultural intelligence are higher for East

Africa than for Germany.

\section{Methods}

\section{Participants}

We conducted a cross-sectional survey in East Africa (Uganda and Kenya) and Germany. Data was collected from a convenient sample comprising of 367 self-employed individuals. The East African sample was recruited from the provinces of Kisumu and Kisii in Kenya; and the Central region of Uganda through different 
business forums including meetings, workshops, and seminars. Some were reached at their business premises. This resulted into 283 (143 females, 140 males) fully completed surveys in a period of four months. Germany participants were recruited through online forums for self-employed (in the Marburg-Biedenkopf area). This resulted in 84 responses (44 females, 40 males). Overall, participants' ages ranged from 17 to 79 years, but the majority were young $(M=26.66, S D=8.04)$ and had obtained at least a bachelor degree (50.3\%).

\section{Measures}

The Personal Cultural Orientations (PCO) scale (Sharma, 2010) was used. The PCO is a 40-item instrument measured on a 7-point Likert scale (ranging from $1=$ strongly disagree to 7 = strongly agree). In the present study, only 8 items relating to interdependence and social inequality orientations were used. The reliability (Cronbach $\alpha$ ) for the sub-scales were .88 for interdependence and .80 for social inequality. Sample items are: I feel good when I cooperate with my group members (interdependence), and Unequal treatment for different people is an acceptable way of life for me (social inequality).

\section{Cultural Intelligence}

Van Dyne et al. (2012) Expanded Cultural Intelligence Scale (E-CQS) was adopted. The E-CQS is an expanded version of the Cultural Intelligence Scale (CQS) (Ang et al., 2007). The instrument comprises of 37 items measured on a 7-point Likert scale (ranging from 1 $=$ strongly disagree to $7=$ strongly agree). The scale focuses on eleven (11) sub-dimensions and four (4) dimensions of cultural intelligence; cognitive, meta-cognitive, motivation and behavioral. In the present study, we only measured the behavioral dimension ( 9 items) and observed high reliability, $\alpha$ of .94. A sample item is "I change how I make requests of others depending on their cultural background".

\section{Subjective Success in Self-employment}

The economic perspectives promote the objective measures of success, that is, in terms of financial performance and other objectively verifiable economic parameters. On the other hand, there is increasing recognition that subjective measures that may not necessarily be economic also matter (Baron et al., 2016; Fisher, Maritz, \& Lobo, 2014; Staniewski \& Awruk, 2018). We, therefore, focus on subjective measures, and specifically, job satisfaction. Job satisfaction is recognized as an effective measure of subjective success, which represents the psychological domain of success (Dijkhuizen, Gorgievski, van Veldhoven, \& Schalk, 2016; Staniewski \& Awruk, 2018). In the present study, we adopted 11 items from the revised and shortened Minnesota Job Satisfaction Questionnaire (see items in Hirschfeld, 2000) measured on a 5-point Likert scale (ranging from $1=$ strongly disagree to 5 =strongly agree); which yielded a good Cronbach's alpha coefficient of .86. A sample item is: I am satisfied with the feeling of accomplishment I get from the job.

\section{Statistical analyses}

Regarding cultural orientations, individual-level analyses were used in line with our focus on personal cultural orientations as proposed by (Sharma, 2010) in his reconceptualization 
of Hofstede dimensions of national culture (Hofstede, Hofstede, \& Minkov, 1991; Hofstede, 1984). We also examined the differences among countries regarding the impact of personal cultural orientations on cultural intelligence and success. Hence a moderated mediation regression analysis was applied using Process macro for SPSS (Hayes, 2015) Model 8. The model tests for direct, indirect, moderated direct and moderated indirect effects concurrently in one regression model. Sample bootstrapping (bootstraps set at 5000) was also applied, which is considered an appropriate approach to making inferences about indirect and moderated effects (Hayes, 2015). In all the models, we controlled for the effects of age, sex, and level of education.

\section{Results}

The means, standard deviations, Cronbach's alpha $(\alpha)$ coefficients and correlations of control and study variables are presented in Table 1. Results relating to all hypotheses are presented in Table 2. Given the strong associations between the study variables, multicollinearity diagnostics were made. Results showed that the highest Variance Inflation Factor (VIF) was 2.22 and tolerance of .45; which are within acceptable ranges of $<10$ for VIF and $>.20$ for tolerance (Field, 2009).

The results in Table 2 show that both cultural orientations; social inequality $(B=.40$, $p<.001)$ and interdependence $(B=.29, p<.01)$, related positively to entrepreneurial subjective success (measured in terms of job satisfaction), thus $H 1$ and $H 2$ are supported. Similarly, interdependence orientation $(B=.72, p<.001)$ and social inequality orientation $(B=.52, p<.001)$ were positively related to behavioral cultural intelligence, supporting $H 4 a$. $H 3$ predicts that behavioral cultural intelligence is positively related to subjective success. As shown in both models A and B in Table 2, this hypothesis is supported (Figs. 1, 2, 3).

Hypotheses $4 \mathrm{~b}, 5 \mathrm{a}$ and $5 \mathrm{~b}$ regard the indirect effects as well as the conditional direct and conditional indirect effects of personal cultural orientations on subjective success in self-employment through cultural intelligence, contingent on country, in a manner that indirect effects of success will be positive and higher for self-employed from East Africa given the multiethnic business environment. Two regression models were calculated, one for each personal cultural orientation. Results in Table 2 (model A) show significant interactive effects of interdependence orientation and country on behavioral cultural intelligence

Table 1 Descriptive statistics and variable inter-correlations

\begin{tabular}{|c|c|c|c|c|c|c|c|c|c|c|}
\hline Variables & M & SD & 1 & 2 & 3 & 4 & 5 & 6 & 7 & 8 \\
\hline $\begin{array}{l}\text { 1. Country (East Africa }=0 \text {, Germany }= \\
\text { 1) }\end{array}$ & .23 & .42 & 1 & & & & & & & \\
\hline 2. Age & 26.66 & 8.04 & $.64^{* * *}$ & 1 & & & & & & \\
\hline 3. Sex $($ Female $=0$, Male $=1)$ & .50 & .50 & .01 & .10 & 1 & & & & & \\
\hline $\begin{array}{l}\text { 4. Education (no degree }=0 \text {, degree }= \\
\text { 1) }\end{array}$ & .50 & .50 & $.11^{*}$ & $.21^{* * *}$ & $.17^{* *}$ & 1 & & & & \\
\hline 5. Interdependence & 5.38 & 1.39 & $-.71^{* * *}$ & $-.56^{* * *}$ & -.02 & $-.12^{*}$ & .88 & & & \\
\hline 6. Social inequality & 4.80 & 1.33 & $-.67^{* * *}$ & $-.42^{* * *}$ & -.05 & $-.19^{* * *}$ & $.30^{* * *}$ & .80 & & \\
\hline 7. Behavioral cultural intelligence & 5.50 & 1.00 & $-.40^{* * *}$ & $-.32^{* * *}$ & -.04 & .01 & $.59^{* * *}$ & $.39^{* * *}$ & .94 & \\
\hline 8. Subjective success (job satisfaction) & 3.96 & .88 & .02 & .05 & $-.14^{* *}$ & -.01 & $.49^{* * *}$ & $.47^{* * *}$ & $.62^{* * *}$ & .86 \\
\hline
\end{tabular}


Table 2 Moderated mediation analyses of effect of cultural orientations on subjective success (job satisfaction) through behavioral cultural intelligence

\begin{tabular}{|c|c|c|c|c|c|c|c|c|}
\hline \multirow[t]{3}{*}{ Variables } & \multicolumn{4}{|c|}{ A. Effects of interdependence orientation } & \multicolumn{4}{|c|}{ B. Effects of social inequality orientation } \\
\hline & \multicolumn{2}{|c|}{ Behavioral CQ } & \multicolumn{2}{|c|}{ Subjective success (JS) } & \multicolumn{2}{|c|}{ Behavioral CQ } & \multicolumn{2}{|c|}{ Subjective success (JS) } \\
\hline & $B$ & SE & $B$ & SE & $B$ & SE & $B$ & SE \\
\hline Constant & $5.34^{* * *}$ & .29 & $1.48^{* *}$ & .17 & $5.37^{* * *}$ & .32 & $1.46^{* * *}$ & .35 \\
\hline Age & -.01 & .01 & .02 & .01 & -.01 & .01 & .02 & .01 \\
\hline Sex & -.03 & .08 & $-.20^{* *}$ & .07 & .11 & .08 & -.07 & .07 \\
\hline Education & $.16^{*}$ & .08 & -.06 & .07 & $.26^{* *}$ & .09 & .03 & .07 \\
\hline Country & -.04 & .19 & $.52^{* * *}$ & .14 & $-.53^{*}$ & .26 & $.40^{*}$ & .17 \\
\hline Interdependence & $.72^{* * *}$ & .04 & $.29^{* *}$ & .08 & & & & \\
\hline $\begin{array}{l}\text { Interdependence } \times \\
\text { Country }\end{array}$ & $-.67^{* * *}$ & .09 & $-.31^{* *}$ & .11 & & & & \\
\hline Social inequality & & & & & $.52^{* * *}$ & .04 & $.40^{* * *}$ & .05 \\
\hline $\begin{array}{l}\text { Social inequality } \times \\
\text { Country }\end{array}$ & & & & & $-.69^{* * *}$ & .10 & $-.56^{* * *}$ & .08 \\
\hline Behavioral CQ & & & $.38^{* * *}$ & .08 & & & $.35^{* * *}$ & .05 \\
\hline$R^{2}$ & .56 & & .44 & & .41 & & .54 & \\
\hline$F$ & $106.21^{* * *}$ & & $26.12^{* * *}$ & & $57.64^{* * *}$ & & 37. $18^{* * *}$ & \\
\hline \multicolumn{9}{|l|}{ Conditional direct effects } \\
\hline Levels of the moderator & Effect & $\begin{array}{l}\text { Boot } \\
\text { SE }\end{array}$ & $\mathrm{LLCl}$ & ULCI & Effect & $\begin{array}{l}\text { Boot } \\
\text { SE }\end{array}$ & $L L C l$ & ULCI \\
\hline East Africa & .36 & .10 & .16 & .56 & .52 & .06 & .40 & .65 \\
\hline Germany & .06 & .07 & -.08 & .19 & -.03 & .05 & -.13 & .08 \\
\hline \multicolumn{9}{|c|}{ Conditional indirect effects } \\
\hline Levels of the moderator & Effect & $\begin{array}{l}\text { Boot } \\
\text { SE }\end{array}$ & $\mathrm{LLCl}$ & ULCI & Effect & $\begin{array}{l}\text { Boot } \\
\text { SE }\end{array}$ & LLCl & ULCI \\
\hline East Africa & .33 & .06 & .21 & .45 & .23 & .03 & .18 & .30 \\
\hline Germany & .08 & .04 & .02 & .16 & -.01 & .03 & -.07 & .06 \\
\hline \multicolumn{9}{|c|}{ Index of moderated mediation } \\
\hline Mediator & Index & $\begin{array}{l}\text { Boot } \\
\text { SE }\end{array}$ & LLCl & ULCI & Index & $\begin{array}{l}\text { Boot } \\
\text { SE }\end{array}$ & $L L C l$ & ULCI \\
\hline Behavioral CQ & -.20 & .08 & -.36 & -.06 & -.24 & .05 & -.35 & -.16 \\
\hline
\end{tabular}

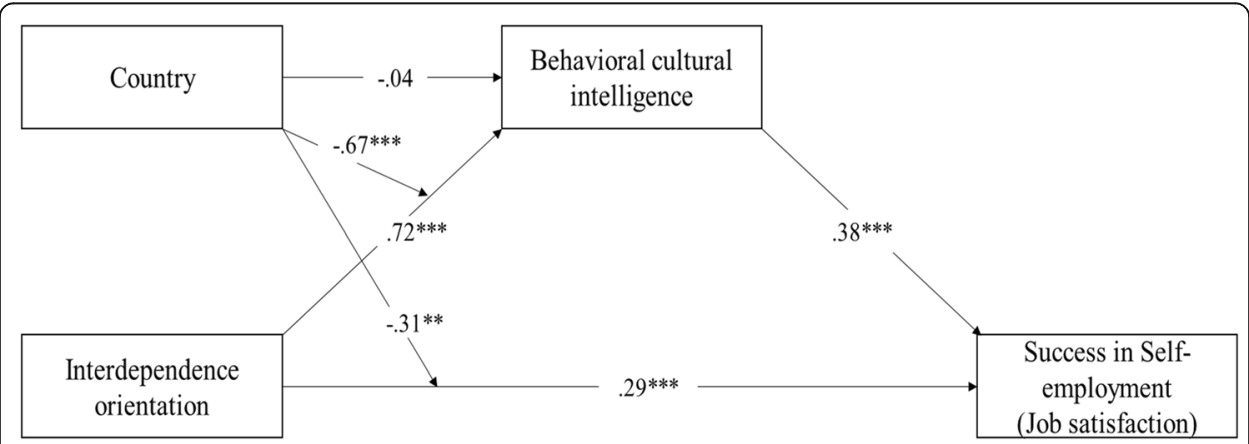

Fig. 1 Moderated mediation effects of interdependence orientation on success through behavioral cultural intelligence 


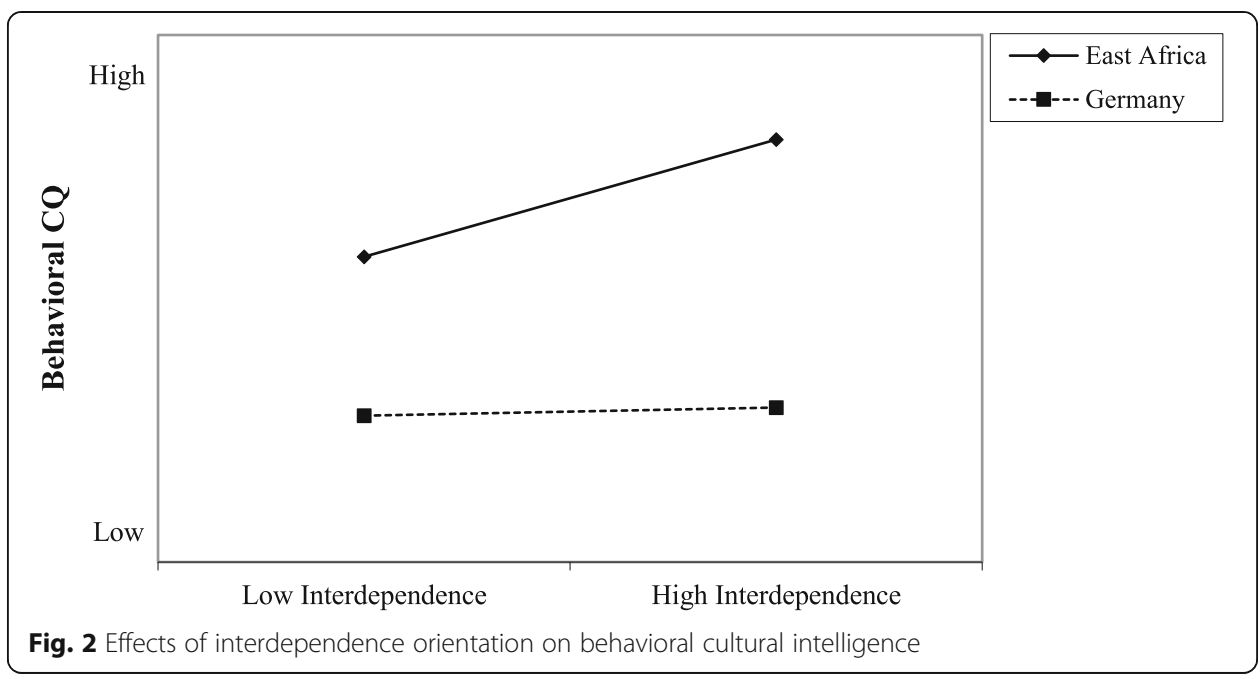

$(B=-.67, p<.001)$ as well as on subjective success $(B=-.31, p<.01)$. These effects are visualized in Figs. 2 and 3, which show that both behavioral cultural intelligence and subjective success were higher for East African participants and were highest at a high level of interdependence orientation. On the other hand, behavioral cultural intelligence and subjective success were lower and almost the same across levels of interdependence orientation for the German participants. Results in Table 2 (model B) further show significant interactive effects of social inequality orientation and country on behavioral cultural intelligence ( $B=$ $-.69, p<.001)$ and subjective success $(B=-.56, p<.001)$. The conditional direct and conditional indirect effect show that interactive effects were positive and significant for the East African sample, but negative and rather marginal for the German Sample. For East African sample, behavioral cultural intelligence and subjective success were highest at high levels of social inequality orientation (see Figs. 5 and 6). These conditional effects provide support for $H 5 a$ and $H 5 b$ (Figs. 4, 5, 6).

Process macro model 8 computes an index of moderated mediation, which represents the slope of the line relating the indirect effects to the conditioning variable (Hayes, 2015). The index of moderated mediation was significant for model A (index $=-.20, C I$ $=-.36$ to -.06$)$. Hence, the effects of interdependence orientation on subjective success were mediated by cultural intelligence; and moderated by country. Conditional indirect effects for this model reveal that mediation occurred for both East African sample ( $B$ $=.33 C I=.21$ to .45$)$ and German sample $(B=.08, C I=.02$ to .16$)$. Regarding effects of social inequality orientation on subjective success through behavioral cultural orientation and conditioned by country; the index of moderated mediation was significant (index $=-.24, \mathrm{CI}=-.35$ to -.16 ). However, the conditional indirect effects were only significant for the East African sample $(\mathrm{B}=.23, \mathrm{CI}=.18$ to .30$)$. Therefore, mediation did not occur for the German sample. These findings further lend support to H4, H5a, and $H 5 b$ and the general moderated mediation model.

\section{Discussion}

The present study was aimed at examining the association between personal cultural orientations, behavioral cultural intelligence and subjective success in self-employment. The study particularly focuses on interdependence and social inequality orientations. In 


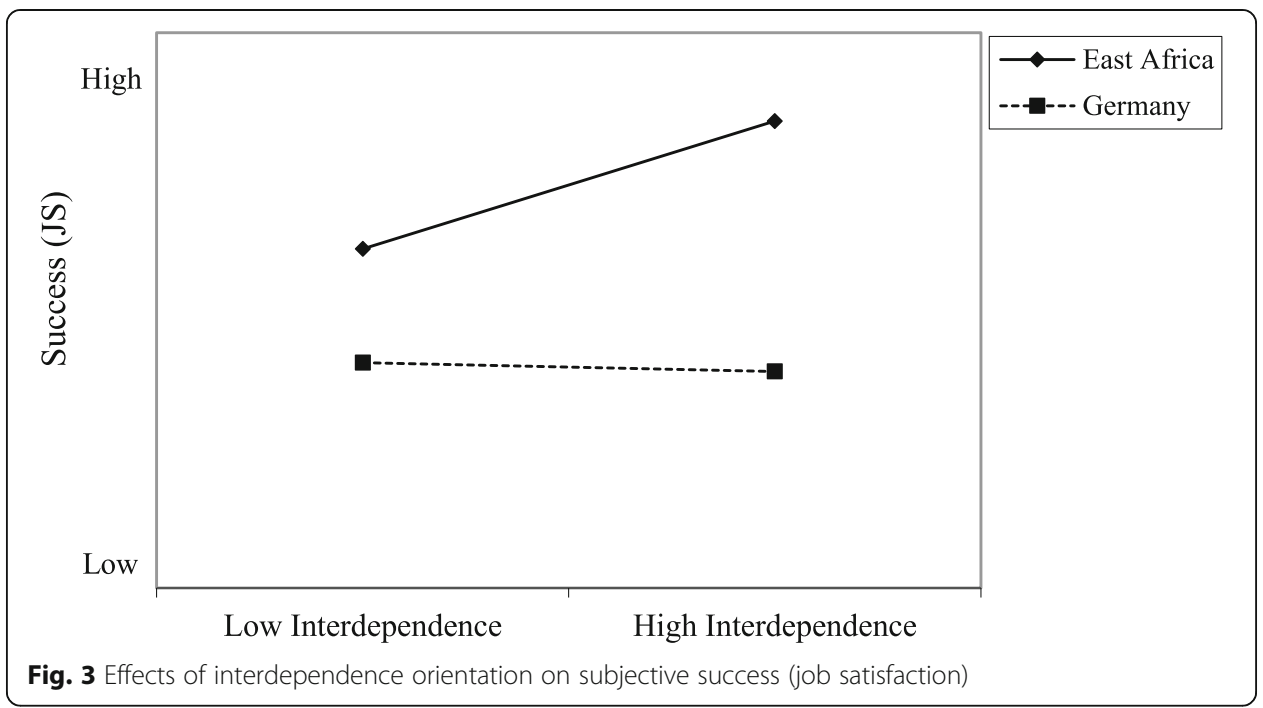

line with literature on the usefulness of social competence in entrepreneurship (Baron and Markman 2000, 2003), the social skills of entrepreneurs are important. They play a role in determining the quality of interactions of the entrepreneur with his or her social environment, therefore, directly and indirectly, affecting success in entrepreneurial activities.

In this direction, Results of $H 4 a$ reveal that both interdependence and social inequality orientations are positively related to behavioral cultural intelligence. Interdependence cultural orientation regards an individual's tendency to value interpersonal reliance and collective action. Similarly, social inequality orientation concerns the acceptance of social differences (Sharma, 2010). Consequently, these orientations sensitize individuals to differences among people as well as how to relate to others. In a multiethnic context where individuals value differences, yet relying on each other, individuals are likely to grow up appreciating cultural differences and yet facilitating the development of the ability to relate with people from various cultural and social backgrounds.

Results concerning $H 1, H 2$, and $H 3$, show that interdependence, social inequality, and cultural intelligence were positively related to subjective success in self-employment. The sense of this can be derived from the study context with specific reference to the East African participants. Particularly for less developed countries, individuals are likely to assess their success in self-employment mostly in terms of how their ventures are

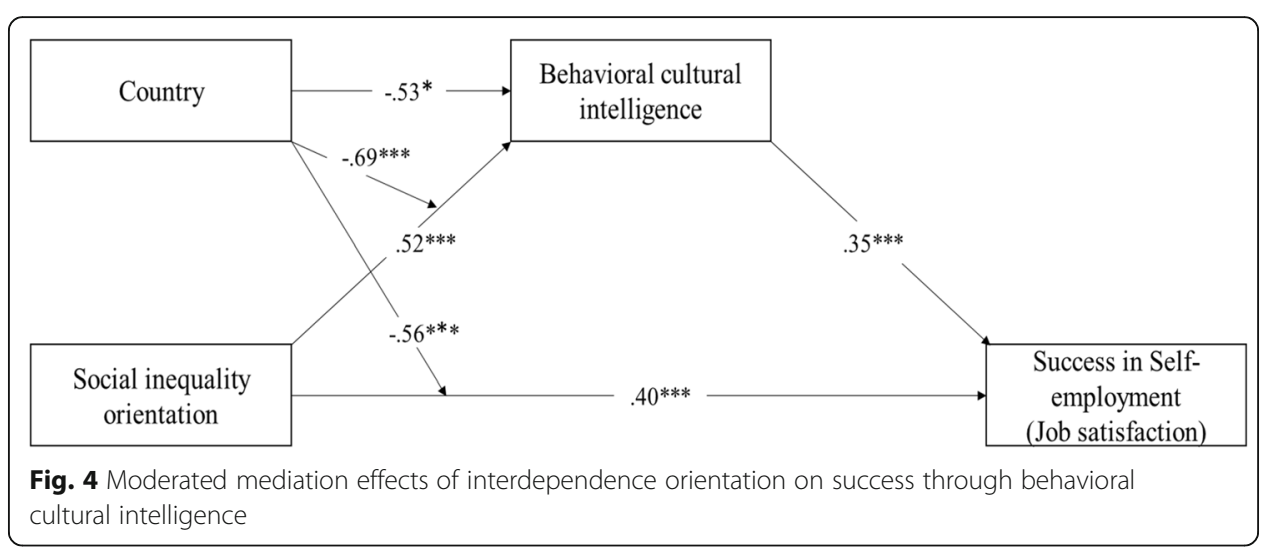




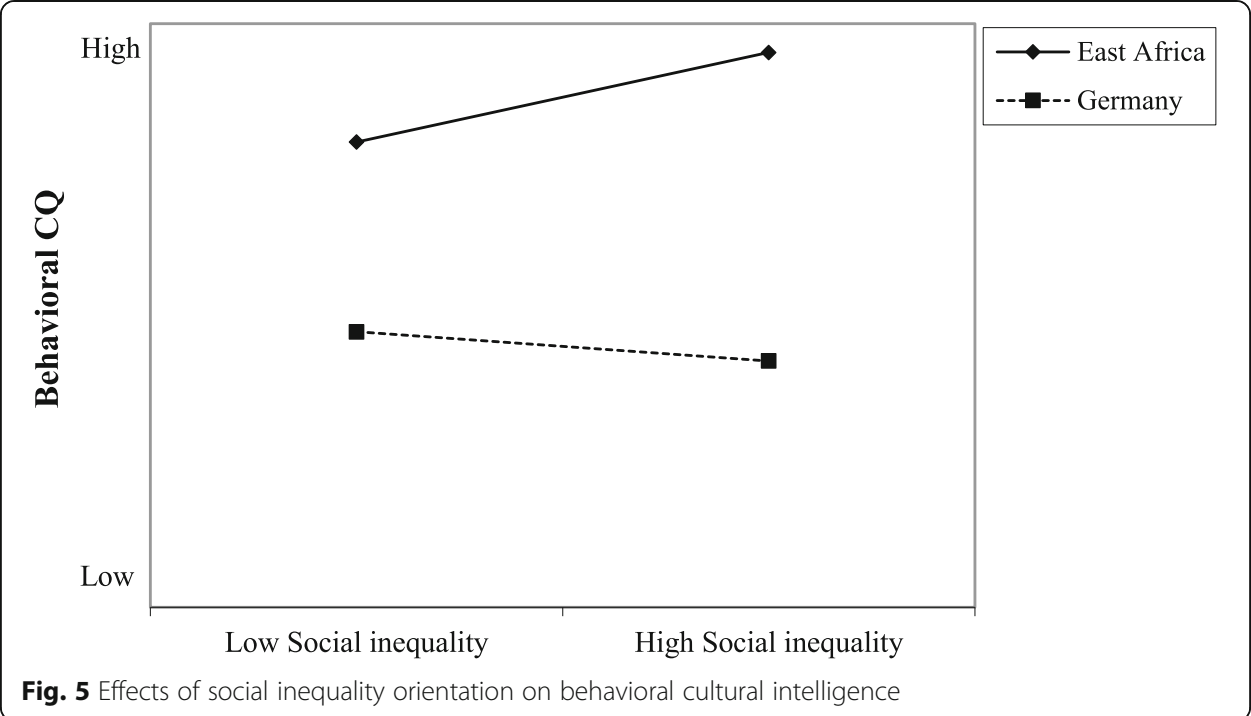

enabling them to achieve their life goals and responsibilities. Some of such goals and responsibilities are premised on interdependence values; for example, the need to meet the survival needs of the family and providing employment for family members. In this direction, coupled with high unemployment rates, self-employment may be motivated by the need to ensure sustained household income, rather than the accumulation of wealth (Eijdenberg, 2016), which then provides the basis for evaluating their success. Therefore, although the competitive and winning mentality is useful for objective success (Giazitzoglu \& Down, 2017; Hamilton, 2000), the ability to meet social responsibilities and other non-economic goals are essential in achieving subjective success. In addition, our results also support previous findings that collectivism is also important for entrepreneurial development in some contexts (e.g. Zeffane 2014). They also provide support for the claim that interdependence or collective action is important to entrepreneurship during the implementation phases (Rauch et al., 2013), hence essential for success.

Concerning the mediation effects, results of $H 4 b$ reveal that the effects of inter interdependence and social inequality orientations on subjective success (job satisfaction) in self-employment are mediated by behavioral cultural intelligence. From this finding, it is posited therefore that behavioral cultural intelligence is one of the important social competencies that are resourceful for successful self-employment, especially in making individual-level cultural values relevant to business situations. Effects of personal cultural orientations on subjective success in self-employment are enhanced by or implemented through cultural intelligence. However, on a general level, the literature shows that some cultural orientations increase cultural intelligence, while others reduce it (Chao et al., 2017). We observe that the orientations measured in this study, interdependence and social inequality, are positively correlated to behavioral cultural intelligence. This aspect of cultural intelligence is directly relevant to behavior during business transacting. Existing research shows that motivational cultural intelligence is, for example, associated with amount of cultural sales (Chen, Liu, \& Portnoy, 2012). An individual with higher cultural intelligence is more likely to have higher sales to people of different cultures or from different groups. In the contemporary globalized business environment, this might be important for boosting business sales, hence enhancing 


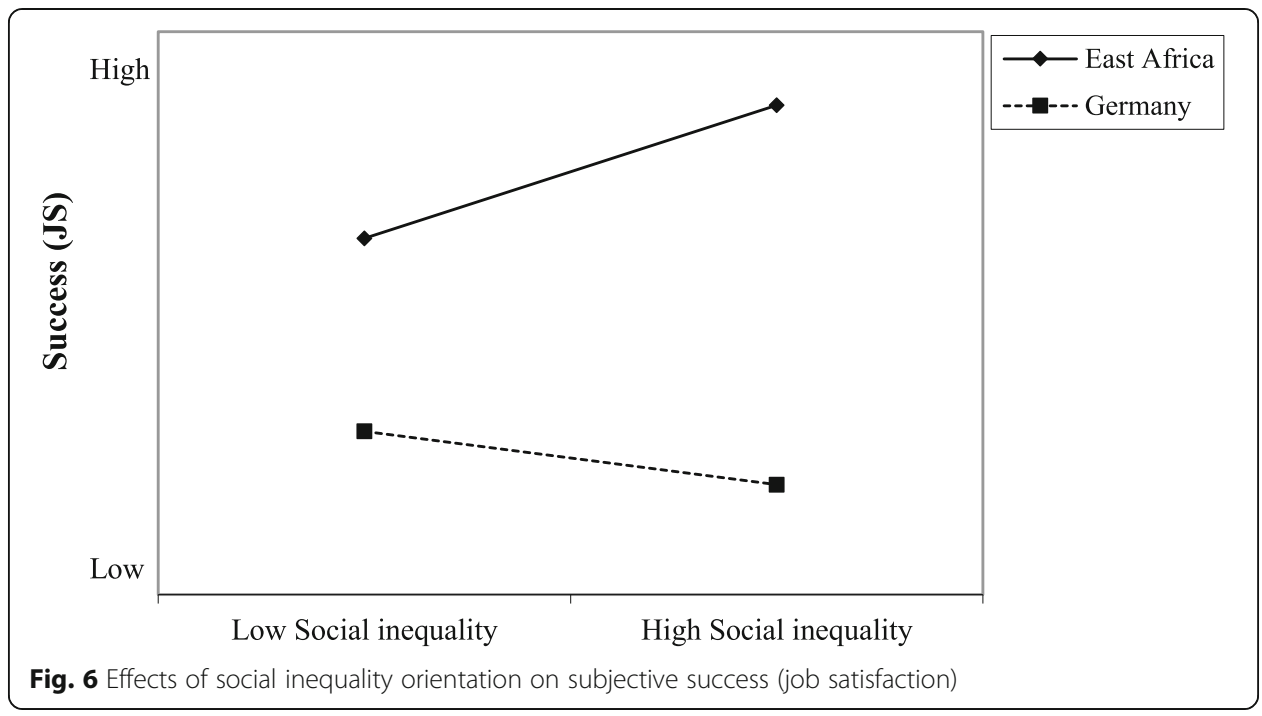

chances of success; and the overall job satisfaction of the self-employed. The present study shows that this is also important to multiethnic, multi-lingual business contexts, in comparison to doing business in relatively culturally homogenous contexts.

The relevance of a particular cultural orientation to success in self-employment or other business related activities is further dependent on the economic and social context. The results of the moderated mediation revealed that both direct and indirect effects of cultural orientations on success vary among countries ( $H 5 a$ and $H 5 b$ ). The study findings reveal interdependence and social inequality orientations relate positively to subjective success in self-employment in East Africa. But this was not true for Germany, where people tend to value independence more than interdependence (Mintu, 1992). Similarly, the indirect effects were higher for the East African sample than for the German sample; which is also an indication of wide social class gaps in the East African communities compared to Germany. These results justify the assumption that differences in social class are important for entrepreneurship. Whereas literature shows that social class is beneficial only for those in the higher socio-economic group (Anderson \& Miller, 2003) in a sense that their high-class networks and access to capital enable them to succeed. On the other hand, in a world marked by high corruption and inequality in job distributions, those in the disadvantaged group view self-employment as a feasible alternative to obtaining meaningful employment, as well as an opportunity to improve their social status. This, therefore, explains the positive relationship between social inequality orientation and subjective success in self-employment in the East African sample.

Our findings also re-affirm the importance of social competence in entrepreneurial success (Baron and Markman 2000). Relational competencies are particularly essential for managing small-scale enterprises in developing countries (Baluku, Kikooma, \& Kibanja, 2016a) but also in multiethnic contexts. The quality of relations of the entrepreneur with significant others affects the ability to obtain funding, credit facilities, participating in entrepreneurial promotion forums, and capital resources. Previous evidence, for example, shows that some self-employed start or sustain businesses with resources provided by friends and family members (Baluku et al., 2016b; Orobia, Sserwanga, \& Rooks, 2011). These demonstrate the value of interdependence in self-employment in less developed countries. 
Moreover, business transactions quite often occur in a social context (Gedajlovic, Honig, Moore, Payne, \& Wright, 2013). This context involves the self-employed person interacting with several people including suppliers, customers, employees, and investors. The quality of relations with each of these contributes directly or indirectly to success. In low socio-economic communities, the quality of social relations with stakeholders plays extra important roles, such as obtaining interest-free (or low-interest) loans and donations for starting-up a self-employment business. In the context of selling, the seller-buyer relationship is crucial to the success of the business (Villena, Revilla, \& Choi, 2011). In a multi-ethnic context such as that of Uganda and Kenya, relational capital is partly constituted by the ability to successfully interact with people from other ethnic groups, thus highlighting the importance of cultural intelligence. The principal contribution of social-cultural competencies such as behavioral cultural intelligence is that it enables the business to attract and retain customers, suppliers, and network with people from other groups; which is facilitated the ability to interact effectively with individuals from other ethnic and linguistic backgrounds.

\section{Conclusion}

To test the hypotheses of this study, survey data was collected from 367 participants from East Africa and Germany, who were mostly young individuals. Job satisfaction is used as a proxy measure of subjective success in self-employment. The assumption is that successful entrepreneurs show higher job satisfaction than less successful ones.

Self-employment is increasingly becoming a popular form of employment. Whereas for the old people, self-employment is a way of remaining productive and earning money after retirement; for the young ones, it is a feasible form of employment, hence a path to successful career life. With the predictions of increasing unemployment, it is imperative that self-employed are supported to succeed and remain in self-employment. This is not only noble in the sense that it increases entrepreneurship and economic development, but also can attract more individuals to this career path. Hence, the present study has practical implications for the promotion of successful entrepreneurship in less developed countries. It is posited that developing the relational resources, including cultural values that enhance cooperation in business, are critical to entrepreneurial success in less developed and collectivistic cultures.

Theoretically, the present study builds on a growing body of knowledge about the role of culture in entrepreneurial success to reaffirm that the so-called less entrepreneurial cultures are not necessarily bad for entrepreneurship. Their usefulness depends on the context. Cultural orientations such as interdependence and social inequality facilitate the development of cultural and social competencies that are for example useful in accumulating social and relational capitals, in turn, increase the likelihood of entrepreneurial success. In addition, the findings of the present study highlight the need to focus beyond financial dimensions of entrepreneurial success, especially in the discourse of entrepreneurial success in less developed countries. Many entrepreneurs in such countries are likely to be motivated by the need to generate adequate funds to finance their families' day-to-day basic needs, rather than amassing wealth. 


\section{Limitations and directions for further research}

The study has some shortcomings. Self-employment success was measured in terms of job satisfaction only. Whereas a focus on subjective success has been advocated for, focusing on both objective and subjective success indicators is likely to generate more robust findings. Additionally, cultural orientations and cultural intelligence impact on entrepreneurs' behaviors (Abdul Malek \& Budhwar, 2013; de la Garza Carranza and Egri, 2010; Krueger et al., 2013; Mueller \& Thomas, 2001) that also have connotations for objective outcomes of self-employment. It is also probable that culture and cultural intelligence could have more impact on objective than subjective success. Future research can further investigate the effects of personal cultural orientations and cultural intelligence on both objective and subjective success. It could be essential to study different aspects of success including entrepreneurial performance, firm growth, and profitability. Moreover, studying the effects of each factor of cultural intelligence might contribute to the literature and important for self-employment support programs.

Measurements were also based on self-reports, whereby participants are prone to inflate ratings of their perceived success. Moreover, the study was cross-sectional focusing predominantly on young self-employed individuals in East African and Germany. The two countries differ significantly in the development level, and therefore also differ in entrepreneurship levels; including the nature of entrepreneurship (opportunistic versus necessity entrepreneurship). These difference could be contributing to the observed differences between East African and German samples. The sample also comprised of mostly young individuals. Therefore, caution has to be taken when generalizing results of the present study to the population of older self-employed persons, and to the self-employed in other countries.

One question for future research arising from our findings is whether the so-called entrepreneurial culture is universal, or is defined by the development context. Extant literature on entrepreneurial culture emphasizes cultural dimensions such as masculinity, individualism and long-term orientation (Hamilton, 2000; Hamilton, 2013; Hofstede \& Minkov, 2010) highlighting the motivations for entrepreneurial action to include the need for accumulating wealth and self-centeredness. Results of the present study, however, suggest that interdependence, appreciation of social inequalities in society and the ability to interact with people from different ethnic backgrounds are important as well. In the context of low-income countries with limited development opportunities, and corruption in the recruitment process, individuals in low social class may lose hope in finding salaried employment; hence self-employment is the most available opportunity to earn income and improve one's social status. Achieving these are important for their job satisfaction or their evaluation of subjective success.

Acknowledgements

We acknowledge the support from Makerere University School of Psychology, Department of Educational, Social, and Organizational Psychology. We also thank Prof. Anakalo (Vice-Chancellor - Research at Kisii University) for the support. The authors also acknowledge the contributions of Ms. Jamia Namuli and Mr. Manuel Menning for their contribution during the data collection process.

Funding

The authors did not receive any funding for this study. 


\section{Authors' contributions}

$M M B$, is the main author of the manuscript. He drafted the manuscript and ensured that it's complete. Also coordinating the inputs of all the authors. JFK, had the main effort in collecting data in Uganda. And participated in the conceptualization and analysis. EB, participated in collecting data in Kenya and participated in conceptualization and aanalysis of data. PO, participated in data collection in Kenya and also in the analysis of data. KO, provided overall oversight; providing the technical advice and support in conducting the study. All authors read and approved the final manuscript.

\section{Competing interests}

The authors declare that they have no competing interests.

\section{Publisher's Note}

Springer Nature remains neutral with regard to jurisdictional claims in published maps and institutional affiliations.

\section{Author details}

${ }^{1}$ Department of Educational, Organizational and Social Psychology, Makerere University, School of Psychology, P.O Box 7062, Kampala, Uganda. ²Faculty of Education \& Human Resource, Kisii University, P.O Box 408, Kisii 40200, Kenya.

${ }^{3}$ Faculty of Psychology, Work and Organizational Psychology, Philipps-Universität, Gutenbergstr 18, D-35032 Marburg, Germany. ${ }^{4}$ Department of Psychology, Maseno University, Private Bag, Maseno, Kenya.

Received: 27 October 2018 Accepted: 20 December 2018

Published online: 07 January 2019

\section{References}

Abdul Malek, M., \& Budhwar, P. (2013). Cultural intelligence as a predictor of expatriate adjustment and performance in Malaysia. Journal of World Business, 48(2), 222-231. https://doi.org/10.1016/j.jwb.2012.07.006.

Al-Dajani, H., \& Marlow, S. (2013). Empowerment and entrepreneurship: A theoretical framework. Int J Entrep Behav Res, 503524. https://doi.org/10.1108/JJEBR-10-2011-0138.

Anderson, A. R., \& Miller, C. J. (2003). "Class matters": Human and social capital in the entrepreneurial process. The Journal of Socio-Economics, 32(1), 17-36. https://doi.org/10.1016/S1053-5357(03)00009-X.

Ang, S., Van Dyne, L., Koh, C., Ng, K. Y., Templer, K. J., Tay, C., \& Chandrasekar, N. A. (2007). Cultural Intelligence : Its measurement and effects on cultural judgment and decision making, cultural adaptation and task performance. Management and Organization Review, 3(3), 335-371. https://doi.org/10.1111/j.1740-8784.2007.00082.x.

$\mathrm{Au}$, K. Y. (2000). Intra-cultural variation as another construct of international management: A study based on secondary data of 42 countries. Journal of International Management, 6(3), 217-238. https://doi.org/10.1016/S1075-4253(00)00026-0.

Autio, E., Pathak, S., \& Wennberg, K. (2013). Consequences of cultural practices for entrepreneurial behaviors. Journal of International Business Studies, 44(4), 334-362. https://doi.org/10.1057/jibs.2013.15.

Baluku, M. (2017). The self-employment process: A discourse of psychological attributes and entrepreneurial socialization. PhilippsUniversitaet Marburg.

Baluku, M. M., Bantu, E., \& Otto, K. (2018). The effect of locus of control on entrepreneurial attitudes and self-employment intentions: The moderating role of individualism. Journal of Enterprising Culture, 26(3), 1-33. https://doi.org/10.1142/S0218495818002073.

Baluku, M. M., Kikooma, J. F., Bantu, E., \& Otto, K. (2018). Psychological capital and entrepreneurial outcomes : The moderating role of social competences of owners of micro- enterprises in East Africa. Journal of Global Entrepreneurship Research, 8(1), 26. https://doi.org/10.1186/s40497-018-0113-7.

Baluku, M. M., Kikooma, J. F., \& Kibanja, G. M. (2016a). Does personality of owners of micro enterprises matter for the relationship between startup capital and entrepreneurial success? African Journal of Business Management, 10(1), 13-23. https://doi.org/10.5897/AJBM2015.7738.

Baluku, M. M., Kikooma, J. F., \& Kibanja, G. M. (2016b). Psychological capital and the startup capital-entrepreneurial success relationship. Journal of Small Business \& Entrepreneurship, 28(1), 27-54. https://doi.org/10.1080/08276331.2015.1132512.

Baluku, M. M., Löser, D., Otto, K., \& Schummer, S. E. (2018). Career mobility in young professionals: How a protean career personality and attitude shapes international mobility and entrepreneurial intentions. Journal of Global Mobility. https://doi.org/10.1108/JGM-10-2017-0041.

Baron, R. A., Franklin, R. J., \& Hmieleski, K. M. (2016). Why entrepreneurs often experience low, not high, levels of stress: The joint effects of selection and psychological capital. Journal of Management, 42(3), 742-768. https://doi.org/10.1177/0149206313495411.

Baron, R. A., \& Markman, G. D. (2000). Beyond social capital: How social skills can enhance entrepreneurs' success. Academy of Management Perspectives, 14(1), 106-116. https://doi.org/10.5465/AME.2000.2909843.

Baron, R. A., \& Markman, G. D. (2003). Beyond social capital: The role of entrepreneurs' social competence in their financial success. Journal of Business Venturing, 18(1), 41-60. https://doi.org/10.1016/S0883-9026(00)00069-0.

Bogilović, S., \& Škerlavaj, M. (2016). Metacogonitive and motivational cultural intelligence: Superpowers for creativity an a culturally diverse environment. Economic and Business Review, 18(1), 55-76.

Brislin, R., Worthley, R., \& Macnab, B. (2006). Cultural intelligence: Understanding behaviors that serve People's goals. Group \& Organization Management, 31(1), 40-55. https://doi.org/10.1177/1059601105275262.

Bruton, G. D., Ketchen, D. J., Jr., \& Ireland, R. D. (2013). Entrepreneurship as a solution to poverty. Journal of Business Venturing, 28(6), 683-689. https://doi.org/10.1016/j.jbusvent.2013.05.002

Bullough, A., Renko, M., \& AbdelZaher, D. (2013). Women's entrepreneurship: Operating within the context of institutional and in-group collectivism. Academy of Management Proceedings, 2013(1), 12047-12047. https://doi.org/10.5465/AMBPP.2013.12047abstract. 
Caliendo, M., Hogenacker, J., Künn, S., \& Wießner, F. (2015). Subsidized start-ups out of unemployment: A comparison to regular business start-ups. Small Business Economics, 45(1), 165-190. https://doi.org/10.1007/s11187-015-9646-0.

Chand, M., \& Ghorbani, M. (2011). National culture, networks and ethnic entrepreneurship: A comparison of the Indian and Chinese immigrants in the US. International Business Review, 20(6), 593-606. https://doi.org/10.1016/j.ibusrev.2011.02.009.

Chao, M. M., Takeuchi, R., \& Farh, J.-L. (2017). Enhancing cultural intelligence: The roles of implicit culture beliefs and adjustment. Personnel Psychology, 70(1), 257-292. https://doi.org/10.1111/peps.12142.

Charoensukmongkol, P. (2016). Cultural intelligence and export performance of small and medium enterprises in Thailand: Mediating roles of organizational capabilities. International Small Business Journal, 34(1), 105-122. https://doi.org/10.1177/0266242614539364.

Chen, X.-P., Liu, D., \& Portnoy, R. (2012). A multilevel investigation of motivational cultural intelligence, organizational diversity climate, and cultural sales: Evidence from U.S. real estate firms. Journal of Applied Psychology, 97(1), 93-106. https://doi.org/10.1037/a0024697.

Coleman, S. (2007). The role of human and Financial Capital in the Profitability and Growth of women-owned small firms. Journal of Small Business Management, 45(3), 303-319. https://doi.org/10.1111/j.1540-627X.2007.00214.x.

Cooper, A. C., Gimeno-Gascon, F. J. J., \& Woo, C. Y. (1994). Initial human and financial capital as predictors of new venture performance. Journal of Business Venturing, 9(5), 371-395. https://doi.org/10.1016/0883-9026(94)90013-2.

Crowne, K. A. (2008). What leads to cultural intelligence? Business Horizons, 51(5), 391-399. https://doi.org/10.1016/j.bushor.2008.03.010.

Crowne, K. A. (2013). Cultural exposure, emotional intelligence, and cultural intelligence: An exploratory study. International Journal of Cross Cultural Management, 13(1), 5-22. https://doi.org/10.1177/1470595812452633.

Davidsson, P. (1995). Culture, structure and regional levels of entrepreneurship. Entrepreneurship \& Regional Development, 7(1), 41-62. https://doi.org/10.1080/08985629500000003.

de la Garza Carranza, M. T., \& Egri, C. P. (2010). Managerial cultural intelligence and small business in Canada. Management Revue, 21(3), 353-371. https://doi.org/10.1688/1861-9908.

Dietrich, H., \& Möller, J. (2016). Youth unemployment in Europe - Business cycle and institutional effects. International Economics and Economic Policy, 13(1), 5-25. https://doi.org/10.1007/s10368-015-0331-1.

Dijkhuizen, J., Gorgievski, M., van Veldhoven, M., \& Schalk, R. (2016). Feeling successful as an entrepreneur: A job demands — Resources approach. International Entrepreneurship and Management Journal, 12(2), 555-573. https://doi.org/10.1007/s11365-014-0354-z.

Dubina, I. N., \& Ramos, S. J. (2016). Creativity through a cultural Lens: The dichotomy of "the west" and "the east" (pp. 29-34). Springer New York. doi:https://doi.org/10.1007/978-1-4939-3261-0_2.

Earley, P. C. (2002). Redefining interactions across cultures and organizations: Moving forward with cultural intelligence. Research in Organizational Behavior, 24, 271-299. https://doi.org/10.1016/S0191-3085(02)24008-3.

Earley, P. C., \& Mosakowski, E. (2004). Cultural intelligence. Harvard Business Review, 82(10), 139-146. https://doi.org/10.1177/1470595808091787.

Earley, P. C., \& Peterson, R. S. (2004). The elusive cultural chameleon: Cultural intelligence as a new approach to intercultural training for the global manager. Academy of Management Learning \& Education, 3(1), 100-115. https://doi.org/10.5465/AMLE.2004.12436826.

Eijdenberg, E. L. (2016). Does one size fit all ? A look at entrepreneurial motivation and entrepreneurial orientation in the informal economy of Tanzania. International Journal of Entrepreneurial Behavior \& Research, 22(6), 804-834. https://doi.org/10.1108/IJEBR-12-2015-0295.

Erez, M., Lisak, A., Harush, R., Glikson, E., Nouri, R., \& Shokef, E. (2013). Going global: Developing management students' cultural intelligence and global identity in culturally diverse virtual teams. Academy of Management Learning \& Education, 12(3), 330-355. https://doi.org/10.5465/amle.2012.0200.

Eroglu, O., \& Picak, M. (2011). Entrepreneurship, National Culture and Turkey. International Journal of Business and Social Science, 2(16), 146-151.

Falco, P., \& Haywood, L. (2016). Entrepreneurship versus joblessness: Explaining the rise in self-employment. Journal of Development Economics, 118, 245-265. https://doi.org/10.1016/j.jdeveco.2015.07.010.

Fernandez, D. R., Carlson, D. S., Stepina, L. P., \& Nicholson, J. D. (1997). Hofstede's country classification 25 years later. The Journal of Social Psychology, 137(1), 43-54. https://doi.org/10.1080/00224549709595412.

Field, A. (2009). Discovering Statistics Using SPSS (3 ed.). In SAGE Publication. Thousand Oaks, CA (3rd ed.). California, USA: Sage.

Fischer, R. (2006). Congruence and functions of personal and cultural values: Do my values reflect my Culture's values? Personality and Social Psychology Bulletin, 32(11), 1419-1431. https://doi.org/10.1177/0146167206291425.

Fisher, R., Maritz, A., \& Lobo, A. (2014). Evaluating entrepreneurs' perception of success. International Journal of Entrepreneurial Behaviour \& Research, 20(5), 478-492. https://doi.org/10.1108/JJEBR-10-2013-0157.

Franke, R. H., Hofstede, G., \& Bond, M. H. (1991). Cultural roots of economic performance: A research noteA. Strategic Management Journal, 12(S1), 165-173. https://doi.org/10.1002/smj.4250120912.

Frederking, L. C. (2004). A cross-national study of culture, organization and entrepreneurship in three neighbourhoods. Entrepreneurship \& Regional Development, 16(3), 197-215. https://doi.org/10.1080/0898562042000197126.

Frey, D. F., MacNaughton, G., Alston, P., Bedggood, M., Frey, D. F., Bodies, C., of the U. H. R. T, \& Vizard, P. (2016). A human rights Lens on full employment and decent work in the 2030 sustainable development agenda. SAGE Open, 6(2), 755829. https://doi.org/10.1177/2158244016649580.

Fritsch, M., Kritikos, A. S., \& Rusakova, A. (2012). Who starts a business and who is self-employed in Germany. SSRN Electronic Journal. https://doi.org/10.2139/ssrn.2006494.

Gedajlovic, E., Honig, B., Moore, C. B., Payne, G. T., \& Wright, M. (2013). Social capital and entrepreneurship: A Schema and research agenda. Entrepreneurship Theory and Practice, 37(3), 455-478. https://doi.org/10.1111/etap.12042.

Giazitzoglu, A., \& Down, S. (2017). Performing entrepreneurial masculinity: An ethnographic account. International Small Business Journal, 35(1), 40-60. https://doi.org/10.1177/0266242615599244.

Gideon, D. M., \& A.Baron, R. (2003). Person - entrepreneurship fit: why some people are moresuccessful as entrepreneurs than others,. Human Resource Management Review, 13,(2), 281-301. 
Gindling, T. H., \& Newhouse, D. (2014). Self-employment in the developing world. World Development, 56, 313-331. https:// doi.org/10.1016/j.worlddev.2013.03.003.

Gore, C. (2015). The Post-2015 moment: Towards sustainable development goals and a new global development paradigm. Journal of International Development, 27(6), 717-732. https://doi.org/10.1002/jid.3109.

Groves, K. S., \& Feyerherm, A. E. (2011). Leader cultural intelligence in context: Testing the moderating effects of team cultural diversity on leader and team performance. Group \& Organization Management, 36(5), 535-566. https://doi.org/10.1177/1059601111415664.

Guess, C. (2004). Decision making in individualistic and collectivistic cultures. Online Readings in Psychology and Culture, 4(1). https://doi.org/10.9707/2307-0919.1032.

Gunkel, M., Schlaegel, C., \& Engle, R. L. (2014). Culture and a cascading model of emotional intelligence: An exploratory analysis. Multinational Enterprises, Markets and Institutional Diversity, 229-257. https://doi.org/10.1108/S1745-886220140000009009.

Hamilton, B. H. (2000). Does entrepreneurship pay? An empirical analysis of the returns to self-employment. Journal of Political Economy, 108(3), 604-631. https://doi.org/10.1086/262131.

Hamilton, E. (2013). The discourse of entrepreneurial masculinities (and femininities). Entrepreneurship \& Regional Development, 25(1-2), 90-99. https://doi.org/10.1080/08985626.2012.746879.

Hayes, A. F. (2015). An index and test of linear moderated mediation. Multivariate Behavioral Research, 50(1), 1-22. https://doi.org/10.1080/00273171.2014.962683.

Hayton, J. C., \& Cacciotti, G. (2013). Is there an entrepreneurial culture? A review of empirical research. Entrepreneurship \& Regional Development, 25(9-10), 708-731. https://doi.org/10.1080/08985626.2013.862962.

Hirschfeld, R. R. (2000). Does revising the intrinsic and extrinsic subscales of the Minnesota satisfaction questionnaire short form make a difference? Educational and Psychological Measurement, 60(2), 255-270. https://doi.org/10.1177/00131640021970493.

Hofstede, G. (1984). Cultural dimensions in management and planning. Asia Pacific Journal of Management, 1(2), 81-99. https://doi.org/10.1007/BF01733682.

Hofstede, G. (1994). The business of international business is. Culture, 3(1), 1-14.

Hofstede, G. (2011). Dimensionalizing cultures: The Hofstede model in context. Online Readings in Psychology and Culture, 2(1). https://doi.org/10.9707/2307-0919.1014.

Hofstede, G., Hofstede, G. J., \& Minkov, M. (2010). Cultures and organizations, software of the mind: Intercultural cooperation and its importance for survival (Vol. 1, 3rd ed.). McGraw Hill. https://doi.org/10.1016/j.cede.2012.04.002.

Hofstede, G., \& Minkov, M. (2010). Long- versus short-term orientation: New perspectives. Asia Pacific Business Review, 16(4), 493-504. https://doi.org/10.1080/13602381003637609.

Houghton, J. D., Wu, J., Godwin, J. L., Neck, C. P., \& Manz, C. C. (2012). Effective stress management: A model of emotional intelligence, self-leadership, and student stress coping. Journal of Management Education, 36(2), 220-238. https://doi.org/ $10.1177 / 1052562911430205$.

Huggins, R., \& Thompson, P. (2014). Culture, entrepreneurship and uneven development: A spatial analysis. Entrepreneurship \& Regional Development, 26(9-10), 726-752. https://doi.org/10.1080/08985626.2014.985740.

Jiang, Z., \& Park, D. S. (2012). Career decision-making self-efficacy as a moderator in the relationships of entrepreneurial career intention with emotional intelligence and cultural intelligence. African Journal of Business Management, 6(30), 8862-8872. https://doi.org/10.5897/AJBM11.1816.

Krueger, N., Linan, F., \& Nabi, G. (2013). Introduction cultural values and entrepreneurship. Entrepreneurship \& Regional Development, 25(9-10), 703-707. https://doi.org/10.1080/08985626.2013.862961.

Lange, T. (2012). Job satisfaction and self-employment: Autonomy or personality? Small Business Economics, 38(2), 165-177. https://doi.org/10.1007/s11187-009-9249-8.

Li, Y., \& Zahra, S. A. (2012). Formal institutions, culture, and venture capital activity: A cross-country analysis. Journal of Business Venturing, 27(1), 95-111. https://doi.org/10.1016/j.jbusvent.2010.06.003.

Lin, Y., Chen, A. S., \& Song, Y. (2012). Does your intelligence help to survive in a foreign jungle? The effects of cultural intelligence and emotional intelligence on cross-cultural adjustment. International Journal of Intercultural Relations, 36(4), 541-552. https://doi.org/10.1016/j.jijintrel.2012.03.001.

Magnusson, P., Westjohn, S. A., Semenov, A., Randrianasolo, A., \& Zdravkovic, S. (2013). The role of cultural intelligence in marketing adaption and export performance. Journal of International Marketing, 21(4), 44-61.

Markman, G. D., \& Baron, R. A. (2003). Person-entrepreneurship fit: Why some people are more successful as entrepreneurs than others. Human Resource Management Review, 13(2), 281-301. https://doi.org/10.1016/51053-4822(03)00018-4.

Markus, H. R., \& Kitayama, S. (1991). Culture and the self: Implications for cognition, emotion, and motivation. Psychological Review, 98(2), 224-253. https://doi.org/10.1037/0033-295X.98.2.224

McGrath, R. G., MacMillan, I. C., Yang, E. A. Y., \& Tsai, W. (1992). Does culture endure, or is it malleable? Issues for entrepreneurial economic development. Journal of Business Venturing, 7(6), 441-458. https://doi.org/10.1016/0883-9026(92)90019-N.

McNulty, J. P., Mackay, S. J., Lewis, S. J., Lane, S., \& White, P. (2016). An international study of emotional intelligence in first year radiography students: The relationship to age, gender and culture. Radiography, 22(2), 171-176. https://doi.org/10.1016/j.radi.2015.10.008.

Migliore, L. A. (2011). Relation between big five personality traits and Hofstede's cultural dimensions: Samples from the USA and India. Cross Cultural Management: An International Journal, 18(1), 38-54. https://doi.org/10.1108/13527601111104287.

Minkov, M., \& Hofstede, G. (2011). The evolution of Hofstede's doctrine. Cross Cultural Management: An International Journal, 18(1), 10-20. https://doi.org/10.1108/13527601111104269.

Minkov, M., \& Hofstede, G. (2012). Hofstede's fifth dimension: New evidence from the world values survey. Journal of CrossCultural Psychology, 43(1), 3-14. https://doi.org/10.1177/0022022110388567.

Mintu, A. T. (1992). Cultures and organizations: Software of the mind. Journal of International Business Studies, 23(2), 362-365. https://doi.org/10.1057/jibs.1992.23.

Mueller, S. L., \& Thomas, A. S. (2001). Culture and entrepreneurial potential: A nine country study of locus of control and innovativeness. Journal of Business Venturing, 16(1), 51-75. https://doi.org/10.1016/S0883-9026(99)00039-7. 
Nabi, G., \& Liñán, F. (2013). Considering business start-up in recession time: The role of risk perception and economic context in shaping the entrepreneurial intent. International Journal of Entrepreneurial Behaviour and Research, 19(6), 633-655. https://doi.org/10.1108/IJEBR-10-2012-0107.

Nabi, G., Liñán, F., Fayolle, A., Krueger, N., \& Walmsley, A. (2017). The impact of entrepreneurship education in higher education: A systematic review and research agenda. Academy of Management Learning \& Education, 16(2), $277-299$. https://doi.org/10.5465/amle.2015.0026.

Naluwooza, M. (2017). Multiethnicity in Makerere University Library services: the effect and implication to the country. Wroclaw, Poland: IFLA.

Neeley, L., \& Van Auken, H. E. (2009). The relationship between owner characteristics and use of bootstrap financing methods. Journal of Small Business and Entrepreneurship, 22(4), 399-412. https://doi.org/10.1080/08276331.2009.10593462.

Orobia, L., Sserwanga, A., \& Rooks, G. (2011). Risk taking and start-up capital: Exploring gender differences in Uganda, through an international comparison. Journal of Economics and Behavioral Studies, 3(2), 83-93.

Ott, D. L., \& Michailova, S. (2016). Cultural intelligence: A review and new research avenues. International Journal of Management Reviews. https://doi.org/10.1111/ijmr.12118.

Oyserman, D. (2006). High power, low power, and equality: Culture beyond individualism and collectivism. Journal of Consumer Psychology, 16(4), 352-356. https://doi.org/10.1207/s15327663jcp1604_6.

Parisotto, A. (2015). Promote sustained, inclusive and sustainable economic growth, full and productive employment and decent work for all. UN Chronicle, 51(4), 19-20. https://doi.org/10.18356/9a54dfe4-en.

Pathak, S., \& Muralidharan, E. (2016). Informal institutions and their comparative influences on social and commercial entrepreneurship: The role of in-group collectivism and interpersonal trust. Journal of Small Business Management, 54(S1), 168-188. https://doi.org/10.1111/jsbm.12289.

Peus, C., Frey, D., Gerkhardt, M., Fischer, P., \& Traut-Mattausch, E. (2009). Leading and managing organizational change initiatives. Management Revue, 20(2), 158-175. https://doi.org/10.1688/1861-9908.

Ramsey, J. R., Barakat, L. L., \& Aad, A. A. (2014). Commitment to the study of international business and cultural intelligence: A multilevel model. Journal of Teaching in International Business, 25(4), 267-282. https://doi.org/10. 1080/08975930.2014.902349

Rauch, A., Frese, M., Wang, Z.-M., Unger, J., Lozada, M., Kupcha, V., \& Spirina, T. (2013). National culture and cultural orientations of owners affecting the innovation-growth relationship in five countries. Entrepreneurship \& Regional Development, 25(9-10), 732-755. https://doi.org/10.1080/08985626.2013.862972.

Reinhart, C. M., \& Rogoff, K. S. (2009). The aftermath of financial crises. American Economic Review, 99(2), 466-472. https://doi. org/10.1257/aer.99.2.466

Sarwar, H., Nadeem, K., \& Aftab, J. (2017). The impact of psychological capital on project success mediating role of emotional intelligence in construction organizations of Pakistan. Journal of Global Entrepreneurship Research, 7(1), 22. https://doi.org/ 10.1186/s40497-017-0080-4.

Schwartz, S. H. (1992). Universals in the content and structure of values: Theoretical advances and empirical tests in 20 countries. Advances in Experimental Social Psychology, 25(C), 1-65. https://doi.org/10.1016/S0065-2601(08)60281-6.

Schwartz, S. H. (1994). Are there universal aspects in the structure and contenst of human values? Journal of Social Issues, 50(4), 19-45. https://doi.org/10.1111/j.1540-4560.1994.tb01196.x.

Sharma, P. (2010). Measuring personal cultural orientations: Scale development and validation. Journal of the Academy of Marketing Science, 38(6), 787-806. https://doi.org/10.1007/s11747-009-0184-7.

Shinnar, R. S., Giacomin, O., \& Janssen, F. (2012). Entrepreneurial perceptions and intentions: The role of gender and culture. Entrepreneurship: Theory and Practice, 36(3), 465-493. https://doi.org/10.1111/j.1540-6520.2012.00509.x.

Smallbone, D., \& Welter, F. (2006). Conceptualising entrepreneurship in a transition context. International Journal of Entrepreneurship and Small Business, 3(2), 190. https://doi.org/10.1504/JJESB.2006.008928.

Soon, A., \& Linn, V. D. (2015). In A. Soon \& V. D. Linn (Eds.), Handbook of Cultural Intelligence. New York: Routledge.

Staniewski, M. W., \& Awruk, K. (2018). Systems approach to entrepreneurial success: The theoretical discussion on the significance of family factors for effective entrepreneurship. In Inside the Mind of the Entrepreneur (pp. 163-174). Springer, Cham. https://doi.org/10.1007/978-3-319-62455-6_12.

Sternberg, R. J. (2004). Culture and intelligence. American Psychologist, 59(5), 325-338. https://doi.org/10.1037/0003-066X.59.5.325.

Sun, S. (2009). Organizational culture and its themes. International Journal of Business and Management, 3(12), 137. https://doi.org/10.5539/ijbm.v3n12p137.

Thébaud, S. (2010). Gender and entrepreneurship as a career choice: Do self-assessments of ability matter? Social Psychology Quarterly, 73(3), 288-304. https://doi.org/10.1177/0190272510377882.

Thomas, D. C. (2006). Domain and development of cultural intelligence: The importance of mindfulness. Group \& Organization Management, 31(1), 78-99. https://doi.org/10.1177/1059601105275266.

Thomas, D. C., Lazarova, M. B., \& Inkson, K. (2005). Global careers: New phenomenon or new perspectives? Journal of World Business, 40(4), 340-347. https://doi.org/10.1016/j.jwb.2005.08.002.

Tiessen, J. H. (1997). Individualism, collectivism, and entrepreneurship: A framework for international comparative research. Journal of Business Venturing, 12(5), 367-384. https://doi.org/10.1016/S0883-9026(97)81199-8.

Tlaiss, H. a. (2014). Women's entrepreneurship, barriers and culture: Insights from the United Arab Emirates. Journal of Entrepreneurship, 23(2), 289-320. https://doi.org/10.1177/0971355714535307.

Triandis, H. C. (2006). Cultural Intelligence in Organizations. Group \& Organization Management, 31(1), $20-26$. https://doi.org/10.1177/1059601105275253.

Tuleja, E. a. (2014). Developing cultural intelligence for global leadership through mindfulness. Journal of Teaching in International Business, 25, 5-24. https://doi.org/10.1080/08975930.2014.881275.

Van Dyne, L., Ang, S., Ng, K. Y., Rockstuhl, T., Tan, M. L., \& Koh, C. (2012). Sub-dimensions of the four factor model of cultural intelligence: Expanding the conceptualization and measurement of cultural intelligence. Social and Personality Psychology Compass, 6(4), 295-313. https://doi.org/10.1111/j.1751-9004.2012.00429.x.

Villena, V. H., Revilla, E., \& Choi, T. Y. (2011). The dark side of buyer-supplier relationships: A social capital perspective. Journal of Operations Management, 29(6), 561-576. https://doi.org/10.1016/j.jom.2010.09.001. 
Vinogradov, E., \& Kolvereid, L. (2010). Home country national intelligence and self-employment rates among immigrants in Norway. Intelligence, 38(1), 151-159. https://doi.org/10.1016/j.intell.2009.09.004.

Vogel, P. (2015a). Generation jobless?: Turning the youth unemployment crisis into opportunity. Generation jobless?: Turning the youth unemployment crisis into opportunity. London, UK: Palgrave Macmillan. https://doi.org/10.1057/9781137375940.

Vogel, P. (2015b). The Youth Unemployment Crisis and the Threat of a "Generation Jobless". In Generation Jobless? (pp. 3-44). London: Palgrave Macmillan UK. https://doi.org/10.1057/9781137375940_1.

Watkins, M., \& Noble, G. (2016). Thinking beyond recognition: Multiculturalism, cultural intelligence, and the professional capacities of teachers. Review of Education, Pedagogy, and Cultural Studies, 38(1), 42-57. https://doi.org/10.1080/10714413.2016.1119642.

Welter, F. (2011). Contextualizing entrepreneurship - Conceptual challenges and ways forward. Entrepreneurship: Theory and Practice, 35(1), 165-184. https://doi.org/10.1111/j.1540-6520.2010.00427.x.

Wennberg, K., Pathak, S., \& Autio, E. (2013). How culture moulds the effects of self-efficacy and fear of failure on entrepreneurship. Entrepreneurship \& Regional Development, 25(9-10), 756-780. https://doi.org/10.1080/08985626.2013.862975.

Wennekers, S., Thurik, R., Van Stel, A., \& Noorderhaven, N. (2010). Uncertainty avoidance and the rate of business ownership across 21 OECD countries, 1976-2004. Entrepreneurship and Culture, 17(2), 271-299. https://doi.org/10.1007/978-3-540-87910-7_13.

Zeffane, R. (2014). Does collectivism necessarily negate the spirit of entrepreneurship? International Journal of Entrepreneurial Behavior \& Research, 20(3), 278-296. https://doi.org/10.1108/JJEBR-03-2013-0042.

Zhao, X., Li, H., \& Rauch, A. (2012). Cross-country differences in entrepreneurial activity: The role of cultural practice and National Wealth. Frontiers of Business Research in China, 6(4), 1-25. https://doi.org/10.3868/s070-001-012-0021-0.

Submit your manuscript to a SpringerOpen ${ }^{\circ}$ journal and benefit from:

- Convenient online submission

- Rigorous peer review

- Open access: articles freely available online

High visibility within the field

- Retaining the copyright to your article

Submit your next manuscript at $\boldsymbol{\nabla}$ springeropen.com 